\title{
Spirulina platensis Alleviating Effect To Rocket Plant (Eruca Vesicaria) Grown On A Pb-Polluted Soil
}

Ali A. abdelsalam¹ ${ }^{1}$, Omar H. Elhoseiny ${ }^{1}$, Hosain A. Abdel-Aziz ${ }^{2}$ and Yasmin H. Ragab ${ }^{2}$

${ }^{1}$ Soil and Water Research Department, Faculty of Agriculture, Moshtohor, Benha University

${ }^{2}$ Soil and Water Research Department, Nuclear Research Center, Atomic Energy Authority

\begin{abstract}
Lead $(\mathrm{Pb})$ is a hazardous heavy metal causing environmental pollution in various sources. A 3-factor pot experiment was conducted to asses the use of Spirulina platensis for alleviating $\mathrm{Pb}$ pollution on rocket plant (Eruca vesicaria) grown in pots $\left(10-\mathrm{kg}\right.$ pot $\left.^{-1}\right)$. Factors and treatments were (1) Pollution (L): non-polluted $\left(\mathrm{L}_{0}\right)$ and polluted soil with $400 \mathrm{mg} \mathrm{Pb} \mathrm{kg}{ }^{-1}\left(\mathrm{~L}_{1}\right)$ as $\mathrm{PbCl}_{2}$ (2) Priming $(\mathrm{P})$ :none $\left(\mathrm{P}_{0}\right)$, priming (soaking) of rocket seeds in $40 \mathrm{mgL}^{-1}\left(\mathrm{P}_{1}\right)$ and $80 \mathrm{mgL}^{-1}\left(\mathrm{P}_{2}\right)$ (3). Spirulina foliar spray $(\mathrm{F})$ : with distilled water $\left(\mathrm{F}_{0}\right), 40 \mathrm{mg} \mathrm{L}^{-1}\left(\mathrm{~F}_{1}\right)$ and $80 \mathrm{mgL}^{-1}\left(\mathrm{~F}_{2}\right)$. Spirulina alleviated contamination and increased growth and photosynthetic pigments and activity as well as increased activity of carboxylating enzymes (Phosphoenol pyruvate carboxylase (PEPC, EC 4.1.1.31) and ribulose1,5-bisphosphate carboxylase (RuBPC, EC 4.1.1.39) and NPK Highest positive effect was by the the combination of foliar and soaking at $80 \mathrm{mg} / \mathrm{l}$ of Spirulina platensis solution.
\end{abstract}

\section{Keywords:}

\section{Introduction}

Lead $(\mathrm{Pb})$ is malleable, heavy and non-corrosive metal and is used in paints, plumbing, batteries, ammunition and petrol (Csuros, 1994; Alloway and Ayres, 1997). It is toxic to plant (Sharma and Dubey 2005; Han et al., 2008; Liu et al. 2008; Zhou et al., 2010) disturbing its morphology, growth and photosynthesis as well as enzyme activities, water imbalance, membrane permeability and nutrition (Patra et al., 2004; Dogan et al., 2009; Ling and Hong, 2009; Maestri et al., 2010 and Nas and Ali 2018). It can damage cells generating reactive oxygen species 'ROS' (Fargasova, 1994; Dixit et al., 2001; Erdei et al., 2002; Islam et al., 2011). ROS such as superoxide radical $\left(\mathrm{O}_{2}{ }^{-}\right)$, singlet oxygen $\left({ }^{1} \mathrm{O}_{2}\right)$, hydrogen peroxide $\left(\mathrm{H}_{2} \mathrm{O}_{2}\right)$ and the hydroxyl radical $(\mathrm{OH}$.) are produced as a result of oxidative stress and detrimental effects to plant cells (Islam et al., 2008).

Photosynthesis is most sensitive to such pollution which decreases chlorophyll contents "probably reduction of $\delta$-aminolevulinic acid dehydratase activity" (Sharma and Dubey, 2005, Cargnelutti et al., 2006; Gonçalves et al., 2009; Rossato et al., 2012), enhances chlorophyll degradation due to high chlorophyllase activity (Drazkiewicz, 1994, Rashid et al., 1994; Gajic et al., 2009) and decreases carotenoids which protects lipids of membranes (Haider et al., 2006; Li et al., 2012). Heavy meyals decrease photosynthetic pigments (Haider et al., 2006; Mishra et al., 2006; Li et al., 2012).

Spirulina platensis algae (blue green alga) can be a biofertilizer and a protein, with vitamins, essential amino acids and fatty acids (Leduy and Thorein, 1977; Ciferri and Tibani, 1985; Vonshak and Richmond, 1985 , Vonshak, 1986 and Ahmed et al., 2011). Jagannath et al. (2002) found that Spirulina increased growth, protein, carbohydrates and grain yield of chick peas ( Cicer arietinum). Liu-ShiMing and
Liang-ShiZhong (1998) noted that cyanobacteria increased roots, epicotyl and hypocotyl growth, and weight of mung beans (Vigna radiate).

Cyanobacteria as biofertilizer increased seed germination, growth parameters and nitrogenous compounds, of wheat (Triticum aestivum), sorghum(Sorghum vulgare), maize (Zea mays), lentil (Lens culinaris ) and sugar beet (Beta vulgaris ) (Adam, 1999; Aly et al., 2008 and Indira and Biswajit, 2012).Spirulina application as foliar spray on radish (Raphanus sativus) increase yield and chlorophyll (Godlewska et al. 2019)

Rocket (Eruca vesicaria subsp. sativa) can grow throughout the year and its fresh green leaves are consumed by the Egyptians for their spicy hot taste. Leaves are rich in nutrients and vitamins and seeds contain medicinal oil ; with an acerage of more than 2200 ha cultivated in Egypt during 2006 (Moussa, 2006).

The present study aims at assessing the effect of treating rocket grown on $\mathrm{Pb}$ polluted soil with Spirulina platensis in alleviating such pollution.

\section{Materials and Methods}

A pot experiment (PVC pots 40-cm high and $35-\mathrm{cm}$ diameter) filled with $10 \mathrm{~kg}$ clay soil was conducted . Table 1 shows main properties of the soil (analysis according to methods cited in Black et al (1965). The experiment was kept in a growth chamber to assess the efficiency of spirulina in decontaminating a $\mathrm{Pb}$ polluted soil and alleviating the negative effect on rocket (Eruca vesicaria subsp. sativa).Seeds were surface sterilized in $0.1 \%(\mathrm{w} / \mathrm{v})$ sodium dodecyl sulphate solution then rinsed with sterile deionized water. The soil was non-saline non-sodic heavy clay. Twenty seeds per pot were seeded and immediately after germination reseeding for non-germinated seeds was done. All pots were supplied with 60, 20 and 40 
$\mathrm{mg}$ of $\mathrm{N}, \mathrm{P}$ and $\mathrm{K}$ respectively per $\mathrm{kg}$ soil as urea (640 $\left.\mathrm{g} \mathrm{Nkg}^{-1}\right)$, super phosphate $\left(68 \mathrm{~g} \mathrm{P} \mathrm{kg}^{-1}\right)$ and potassium sulphate $\left(40 \mathrm{~g} \mathrm{~K} \mathrm{~kg}^{-1}\right)$. The design of the experiment was a Randomized Complete Block, factorial (3 factors) in 3 replicates. Factor 1 is pollution (L): nonpolluted $\left(\mathrm{L}_{0}\right)$ and polluted with $400 \mathrm{mg} \mathrm{Pb} \mathrm{kg}^{-1}\left(\mathrm{~L}_{1}\right)$ as $\mathrm{PbCl}_{2}$ Factor 2 spirulina seed priming $(\mathrm{P})$; none $\left(\mathrm{P}_{0}\right)$, priming in $40 \mathrm{mgL}^{-1}\left(\mathrm{P}_{1}\right)$ and in $80 \mathrm{mgL}^{-1}\left(\mathrm{P}_{2}\right)$ .Priming lasted overnight. Non-primed seeds were soaked in distilled water. Factor 3 spirulina foliar spray $(\mathrm{F})$ with none $\left(\mathrm{F}_{0}\right)$ spray with distilled water, spray with $40 \mathrm{mgL}^{-1}\left(\mathrm{~F}_{1}\right)$ and with $80 \mathrm{mgL}^{-1}\left(\mathrm{~F}_{2}\right)$ Thus the number of treatment combinations $=18(2$ "L" $\mathrm{x}$ 3 "P" x 3 "F" ). Watering was done up to about $85 \%$ of water holding capacity.
Photosynthetic pigments Chlorophyll (Chl $a$, and $\mathrm{Chl}$ $b)$ and carotenoids were determined according to Metzner et al. (1965); Photosynthetic activity $\left({ }^{14} \mathrm{CO}_{2}\right.$ fixation) was assayed as described by Moussa (2006). Activities of carboxylating enzymes (Phosphoenol pyruvate carboxylase "PEPC, EC 4.1.1.31") were measured using a method described by Cánovas and Kornberg (1969) .Ribulose-1,5-bisphosphate carboxylase/oxygenase activity (RuBPC, EC 4.1.1.39) was measured using a method described by Robinson and Portis (1988). N and P were determined using an auto-analyzer (QuikChem, Series 8000, Lachat Instruments Inc., USA), while $\mathrm{K}$ and $\mathrm{Pb}$ were measured using atomic absorption spectrophotometer (Perkin-Elmer 5100 PC).

Table 1. Main properties of the soil used in the experiment

\begin{tabular}{|c|c|c|c|}
\hline Property & Value & \multicolumn{2}{|c|}{ Available nutrient } \\
\hline $\mathrm{pH}\left(1: 2.5 \mathrm{H}_{2} \mathrm{O}\right)$ & 7.55 & $\mathrm{~N}$ & 4.0 \\
\hline $\mathrm{EC}, \mathrm{dS} \mathrm{m}^{-1}$ (Paste extract) & 0.86 & $\mathrm{P}$ & 4.1 \\
\hline ESP & 0.52 & $\mathrm{~K}$ & 100 \\
\hline Organic Matter $\left(\mathrm{g} \mathrm{kg}^{-1}\right)$ & 20.1 & $\mathrm{Fe}$ & 9.9 \\
\hline Sand $\%$ & 31.5 & $\mathrm{Mn}$ & 2.7 \\
\hline Silt \% & 11.8 & $\mathrm{~Pb}$ & 0.01 \\
\hline Clay, $\%$ & 56.7 & $\mathrm{Zn}$ & 0.7 \\
\hline Texture* & Heavy Clay & \multirow{3}{*}{\multicolumn{2}{|c|}{$\begin{array}{l}\text { Extracts: } \mathrm{KCl}(\mathrm{N}) ; \mathrm{NaCHO} 3(\mathrm{P}) \text {; } \\
\mathrm{NH} 4 \mathrm{Ac}(\mathrm{K}) ; \mathrm{DTPA}(\mathrm{Fe}, \mathrm{Mn}, \mathrm{Zn} \mathrm{Cu} \text { and } \mathrm{Pb})\end{array}$}} \\
\hline WHC (w/w) \% & 38.6 & & \\
\hline Bulk Density $\left(\mathrm{Mg} \mathrm{m}^{-3}\right)$ & 1.33 & & \\
\hline
\end{tabular}

\section{Results and Discussion}

Fresh weight of above soil plant growth :

Shoots fresh weight was affected negatively by $\mathrm{Pb}$ contamination and positively by spirulina application (Table 2). The lowest of $210 \mathrm{~g} \mathrm{pot}^{-1}$ occurred upon application of $\mathrm{Pb}$ with no spirulina $\left(\mathrm{L}_{1} \mathrm{P}_{0} \mathrm{~F}_{0}\right)$ while the highest was given by non $\mathrm{Pb}$-contaminated treatment receiving the high dose of both priming and spraying of spirulina $\left(\mathrm{L}_{0} \mathrm{P}_{2} \mathrm{~F}_{2}\right)$ which surpassed the lowest by $552 \%$ which demonstrates a considerable alleviation of the negative effect caused by $\mathrm{Pb}$. The main effect of $\mathrm{Pb}$ contamination was a decrease of $30.8 \%$. The decrease was particularly high - being $46.3 \%$ - where no spirulina was given. In presence of spirulina at its combined high dose of spray+priming the negative effect less approaching $25.6 \%$.The alleviating effect of spraying spirulina surpassed its priming counterpart particularly where the high dose was used. Priming caused increases averaging 26.7 and $66.3 \%$ at the low and high doses respectively compared with 43.7 and $114 \%$ respectively using the spray method.

Roots fresh weight followed a pattern resembling that of the shoots (Table 2). The lowest of $86 \mathrm{~g} \mathrm{pot}^{-1}$ occurred with $\mathrm{Pb}$ without spirulina $\left(\mathrm{L}_{1} \mathrm{P}_{0} \mathrm{~F}_{0}\right)$ and the highest was given by no $\mathrm{Pb}$ treatment receiving the high dose of spirulina priming +spraying $\left(\mathrm{L}_{0} \mathrm{P}_{2} \mathrm{~F}_{2}\right)$ which surpassed the lowest by $631 \%$ indicating an extremely high alleviation effect of growth retardation caused by $\mathrm{Pb}$. The main effect of $\mathrm{Pb}$ contamination was a decrease of $33.5 \%$. The decrease was particularly high amounting to $23.2 \%$, where no spirulina was given. In presence of spirulina at its combined high dose of "spray+priming" the negative effect was a decrease of $50.1 \%$. The alleviating effect of spraying spirulina surpassed its priming counterpart particularly where the high dose was used. The priming effect averaged 41.3 and $94.5 \%$ at the low and high doses respectively compared with 58.5 and $138 \%$ respectively using the spray method.

\section{Contents of carotenoids in shoots:}

Response of carotenoids (Table 2) followed a pattern resembling those of the plant growth. Contents were affected negatively by $\mathrm{Pb}$ and positively by spirulina application. The lowest content of $0.50 \mathrm{mgkg}^{-1}$ f.w. occurred due to $\mathrm{Pb}$ contamination with no spirulina treatment $\left(\mathrm{L}_{1} \mathrm{P}_{0} \mathrm{~F}_{0}\right)$. The highest existed in the non-contaminated high spirulina $\left(\mathrm{L}_{0} \mathrm{P}_{2} \mathrm{~F}_{2}\right)$ plants surpassing the lowest by an extremely high 584\%. Under no spirulina the decease caused by $\mathrm{Pb}$ was $38.3 \%$.The main effect of $\mathrm{Pb}$ contamination was an average decrease of $16.0 \%$. Under the combined high doses of both spirulina methods the decrease by $\mathrm{Pb}$ was $15.2 \%$. The spray method of spirulina was more efficient than the priming method. Increases averaged 38.4 and $112 \%$ by the low and high spray respectively compared with respective averages of 23.2 and $58.3 \%$ by the priming method. 
Table 2. Fresh weight $\left(\right.$ gpot $\left.^{-1}\right)$ of rocket plants and carotenoids in shoots as a affected by contaminating the soil with $\mathrm{Pb}$ and alleviation with Spirulina platensis (blue-green algae)

\begin{tabular}{|c|c|c|c|c|c|c|c|c|c|c|c|c|c|}
\hline \multirow{3}{*}{$\begin{array}{l}\mathrm{Pb} \\
\text { Pollution } \\
\quad(\mathrm{L})\end{array}$} & \multirow{3}{*}{$\begin{array}{l}\text { Seed } \\
\text { primin } \\
(\mathrm{P}) \\
\end{array}$} & \multicolumn{12}{|c|}{ Foliar spray $(\mathrm{F})$} \\
\hline & & $\mathrm{F}_{0}$ & $\mathrm{~F}_{1}$ & $\mathrm{~F}_{2}$ & Mean & $\mathrm{F}_{0}$ & $\mathrm{~F}_{1}$ & $\mathrm{~F}_{2}$ & Mean & $\mathrm{F}_{0}$ & $\mathrm{~F}_{1}$ & $\mathrm{~F}_{2}$ & Mean \\
\hline & & \multicolumn{4}{|c|}{ Shoots $\left(\mathrm{g} \mathrm{pot}^{-1}\right)$} & \multicolumn{4}{|c|}{ Roots $\left(\right.$ g pot $\left.^{-1}\right)$} & \multicolumn{4}{|c|}{ Shoots Carotenoids $\left(\mathrm{mg} \mathrm{kg}^{-1}\right)$} \\
\hline \multirow[t]{3}{*}{$\mathrm{L}_{0}$} & $\mathrm{P}_{0}$ & 391 & 613 & 1150 & 718 & 112 & 285 & 400 & 266 & 0.81 & 1.85 & 2.87 & 1.84 \\
\hline & $\mathrm{P}_{1}$ & 552 & 871 & 1275 & 899 & 208 & 352 & 528 & 363 & 1.40 & 2.08 & 3.16 & 2.21 \\
\hline & $\mathrm{P}_{2}$ & 924 & 993 & 1369 & 1095 & 367 & 498 & 629 & 498 & 2.41 & 2.31 & 3.42 & 2.71 \\
\hline Mean & & 622 & 826 & 1264 & 904 & 229 & 378 & 519 & 376 & 1.54 & 2.08 & 3.15 & 2.25 \\
\hline \multirow[t]{3}{*}{$\mathrm{L}_{1}$} & $\mathrm{P}_{0}$ & 210 & 408 & 729 & 449 & 86 & 112 & 314 & 171 & 0.50 & 1.31 & 2.45 & 1.42 \\
\hline & $\mathrm{P}_{1}$ & 313 & 526 & 903 & 581 & 100 & 180 & 482 & 254 & 1.09 & 1.60 & 2.74 & 1.81 \\
\hline & $\mathrm{P}_{2}$ & 617 & 909 & 1018 & 848 & 227 & 315 & 508 & 350 & 2.08 & 2.35 & 2.90 & 2.44 \\
\hline Mean & & 380 & 614 & 883 & 626 & 138 & 202 & 435 & 250 & 1.22 & 1.75 & 2.70 & 1.89 \\
\hline G. Mean & & 501 & 720 & 1074 & & 183 & 290 & 477 & & 1.38 & 1.91 & 2.92 & 2.07 \\
\hline \multicolumn{14}{|c|}{ Means of $\mathrm{P}$} \\
\hline $\mathrm{P}_{0}$ & & 301 & 511 & 940 & 584 & 99 & 199 & 357 & 218 & 0.65 & 1.58 & 2.66 & 1.63 \\
\hline $\mathrm{P}_{1}$ & & 432 & 699 & 1089 & 740 & 154 & 266 & 505 & 308 & 1.24 & 1.84 & 2.95 & 2.01 \\
\hline $\mathrm{P}_{2}$ & & 770 & 951 & 1193 & 971 & 297 & 406 & 569 & 424 & 2.24 & 2.33 & 3.16 & 2.58 \\
\hline LSD 0.05 & & \multicolumn{4}{|c|}{$\begin{array}{l}\text { L:2.1 P:2.7 F:2.2 LP:3.8 } \\
\text { LF:3.8 PF:1.6 LPF:2.3 }\end{array}$} & \multicolumn{4}{|c|}{$\begin{array}{l}\text { L:0.1 P:0.2 F:0.2 LP:0.2 } \\
\text { LF:0.2 PF:0.3 LPF:0.4 }\end{array}$} & \multicolumn{4}{|c|}{$\begin{array}{l}\text { L:0.09 P:0.001 F:0.001 } \\
\text { LP:0.06 LF:0.01 PF:0.001 } \\
\text { LPF:0.001 }\end{array}$} \\
\hline
\end{tabular}

Notes: $\mathrm{L}_{1}$ and $\mathrm{L}_{2}$ are $\mathrm{Pb}$ pollution of 0 , and $400 \mathrm{mgkg}^{-1}$ respectively (source $\left.\mathrm{Pb} \mathrm{Cl}_{2}\right) ; \mathrm{P}_{0}, \mathrm{P}_{1}$ and $\mathrm{P}_{2}$ are seed soaking (priming) in spirulina suspension (SS) of 0,40 and $80 \mathrm{mgL}^{-1} ; \mathrm{F}_{0}, \mathrm{~F}_{1}$ and $\mathrm{F}_{2}$ are foliar spray with SS of 0,40 and $80 \mathrm{mgL}^{-1}$ respectively.

\section{Contents of Chlorophylla :}

Contents of chlorophyll a were affected negatively by $\mathrm{Pb}$ contamination and positively by spirulina application (Table 3). The lowest content of chlorophyll $_{\mathrm{a}}$ of $0.76 \mathrm{mgkg}^{-1}$ f.w. occurred upon application of $\mathrm{Pb}$ with no spirulina $\left(\mathrm{L}_{1} \mathrm{P}_{0} \mathrm{~F}_{0}\right)$. The highest contents existed in the non $\mathrm{Pb}$-contaminated treatment receiving the high dose of both priming and spraying of spirulina $\left(\mathrm{L}_{0} \mathrm{P}_{2} \mathrm{~F}_{2}\right)$ which surpassed the lowest by $345 \%$ indicating a considerable alleviating effect caused by the combined effect of spirulina seed priming and foliar spray. The main effect of $\mathrm{Pb}$ was an average decrease of $17.1 \%$. The decrease was $40.6 \%$ where no spirulina was given and $12.7 \%$ where spirulina was given at the high dose of the two methods combined. Effectiveness of spirulina spray surpassed its priming counterpart. Spray caused average increases of 37.4 and $101 \%$ by the low and high doses respectively compared with respective 11.8 and $34.9 . \%$ by the priming method.

\section{Contents of chlorophyll $\mathrm{b}_{\mathrm{b}}$ :}

Table 3 shows that results of chlorophyll resemble those of chlorophyll $\mathrm{a}_{\mathrm{a}}$ The lowest chlorophyll $\mathrm{b}_{\mathrm{b}}$ of $0.25 \mathrm{mgkg}^{-1} \mathrm{f}$.w. was given by the $\mathrm{Pb}$ contaminated non-spirulina treated $\left(\mathrm{L}_{1} \mathrm{P}_{0} \mathrm{~F}_{0}\right)$ plants. The highest were given by non- $\mathrm{Pb}$ polluted plants which received combined high doses of spirulina which surpassed the lowest by as much as $864 \%$ demonstrating an extremely alleviating effect against $\mathrm{Pb}$ toxicity. The main effect of $\mathrm{Pb}$ was an average decrease of $37.7 \%$. The decrease was $38.5 \%$ where no spirulina was given and $36.9 \%$ where spirulina was given at the high dose of the two methods combined. Effectiveness of spirulina spray was more than its priming. For the spray method, increases averaged 75.3 and $137 \%$ for the low and high spray dose respectively compared with respective averages of 27.4 and $62.1 \%$.

Contents of chlorophyll $a+b$ :

Table 3 shows that the pattern of response to chlorophyll $a+b$ was very similar to each of chlorophyll $_{\mathrm{a}}$ and chlorophyll $\mathrm{b}_{\mathrm{b}}$.Pb caused a negative effect while spirulina caused a positive one. The lowest chlorophyll $\mathrm{a}_{\mathrm{b}}$ of $1.01 \mathrm{mgkg}^{-1} \mathrm{f}$.w. occurred upon applying $\mathrm{Pb}$ with no spirulina $\left(\mathrm{L}_{1} \mathrm{P}_{0} \mathrm{~F}_{0}\right)$ while the highest existed in the non $\mathrm{Pb}$-contaminated which of the high combined dose of both priming and spraying spirulina $\left(\mathrm{L}_{0} \mathrm{P}_{2} \mathrm{~F}_{2}\right)$ which surpassed the lowest by $422 \%$, reflecting considerable alleviating effect against $\mathrm{Pb}$ contamination .

Main effect of $\mathrm{Pb}$ was a decrease of $25.2 \%$ and the decrease was particularly high of $45.1 \%$ where no spirulina was given but with combined high doses of spirulina, the decrease was lowered to $20.1 \%$. Spirulina was more effective when sprayed than when primed. Spraying caused increases averaging 44.0 and $105 \%$ due to the low and high dose respectively as compared with 10.9 and $32.3 \%$ for the priming methods.

\section{Photosynthetic activity}

The pattern of response regarding photosynthetic activity (Table 4) was in line with those of the chlorophyll pigments. Photosynthetic activity was 
affected negatively by $\mathrm{Pb}$ contamination and positively by spirulina application.

Table 3. Chlorophyll contents ( $\mathrm{mg} \mathrm{kg}^{-1}$ fresh wt.) in shoots of rocket grown on a Pb-contaminated soil as affected with Spirulina platensis treatment

\begin{tabular}{|c|c|c|c|c|c|c|c|c|c|c|c|c|c|}
\hline \multirow{3}{*}{$\begin{array}{l}\text { Soil } \\
\mathrm{Pb} \\
\text { Poll. } \\
\text { (L) }\end{array}$} & \multirow{3}{*}{$\begin{array}{l}\text { Seed } \\
\text { prime } \\
(\mathrm{P})\end{array}$} & \multicolumn{12}{|c|}{ Foliar spray (F) } \\
\hline & & $\mathrm{F}_{0}$ & $\mathrm{~F}_{1}$ & $\mathrm{~F}_{2}$ & Mean & $\mathrm{F}_{0}$ & $\mathrm{~F}_{1}$ & $\mathrm{~F}_{2}$ & Mean & $\mathrm{F}_{0}$ & $\mathrm{~F}_{1}$ & $\mathrm{~F}_{2}$ & Mean \\
\hline & & \multicolumn{4}{|c|}{ Chlorophyll $_{\mathrm{a}}$ ', } & \multicolumn{4}{|c|}{ Chlorophyll } & \multicolumn{4}{|c|}{ Chlorophyll $_{\mathrm{a}+\mathrm{b}}$} \\
\hline \multirow[t]{3}{*}{$\mathrm{L}_{0}$} & $\overline{\mathrm{P}_{0}}$ & 1.28 & 2.08 & 2.92 & 2.09 & 0.85 & 1.33 & 1.87 & 1.26 & 1.84 & 3.40 & 4.79 & 3.34 \\
\hline & $\mathrm{P}_{1}$ & 1.53 & 2.21 & 3.18 & 2.30 & 0.89 & 1.50 & 2.08 & 1.41 & 2.41 & 3.65 & 4.97 & 3.68 \\
\hline & $\mathrm{P}_{2}$ & 2.11 & 2.45 & 3.38 & 2.65 & 1.31 & 1.87 & 2.41 & 1.87 & 3.42 & 3.81 & 5.27 & 4.17 \\
\hline \multicolumn{2}{|l|}{ Mean } & 1.64 & 2.25 & 3.16 & 2.35 & 0.93 & 1.57 & 2.12 & 1.54 & 2.55 & 3.62 & 5.01 & 3.73 \\
\hline \multirow[t]{3}{*}{$\mathrm{L}_{1}$} & $\mathrm{P}_{0}$ & 0.76 & 1.58 & 2.55 & 1.63 & 0.25 & 0.78 & 1.15 & 0.72 & 1.01 & 2.36 & 3.71 & 2.36 \\
\hline & $\mathrm{P}_{1}$ & 1.08 & 1.71 & 2.78 & 1.85 & 0.51 & 0.92 & 1.34 & 0.92 & 1.57 & 2.56 & 3.83 & 2.65 \\
\hline & $\mathrm{P}_{2}$ & 2.03 & 2.14 & 2.95 & 2.37 & 0.85 & 1.29 & 1.52 & 1.22 & 2.83 & 3.08 & 4.21 & 3.37 \\
\hline \multicolumn{2}{|l|}{ Mean } & 1.29 & 1.81 & 2.76 & 1.95 & 0.54 & 1.00 & 1.33 & 0.96 & 1.30 & 2.66 & 3.91 & 2.79 \\
\hline \multicolumn{2}{|c|}{ G. Mean } & 1.47 & 2.02 & 2.96 & & 0.73 & 1.28 & 1.73 & & 2.18 & 3.14 & 4.46 & 3.26 \\
\hline \multicolumn{14}{|c|}{ Means of F } \\
\hline \multicolumn{2}{|l|}{$\mathrm{P}_{0}$} & 1.02 & 1.83 & 2.73 & 1.86 & 0.41 & 1.05 & 1.51 & 0.95 & 1.42 & 2.88 & 4.25 & 2.85 \\
\hline \multicolumn{2}{|l|}{$\mathrm{P}_{1}$} & 1.30 & 1.96 & 2.98 & 2.08 & 0.70 & 1.21 & 1.71 & 1.21 & 1.99 & 3.10 & 4.40 & 3.16 \\
\hline \multirow[t]{4}{*}{$\mathrm{P}_{2}$} & & 2.07 & 2.30 & 3.16 & 2.51 & 1.08 & 1.58 & 1.97 & 1.54 & 3.13 & 3.45 & 4.74 & 3.77 \\
\hline & & $\mathrm{L}: 0.0$ & P: & $2 \quad \mathrm{~F}$ & .001 & $\begin{array}{ll}\mathrm{L} & 0 .\end{array}$ & $01 \mathrm{P}$ & 0.50 & 0.001 & L 0.09 & \multirow{2}{*}{\multicolumn{3}{|c|}{ P0.001 P $0.001 \mathrm{LP}$}} \\
\hline & & LP:0. & & 0.01 & & LP0. & $6 \mathrm{LF}$ & 0.06 & F0.001 & 0.06 & & & \\
\hline & & PF0.0 & & : 0.0 & & LPF & .001 & & & LF 0.0 & $1 \mathrm{LF}$ & 0.001 & \\
\hline
\end{tabular}

See notes of Table 2 for designation of treatments.

The lowest activity of $9.63 \mathrm{kBq}$ mg-1 fw occurred in the $\mathrm{Pb}$-contaminated treatment under conditions of no spirulina $\left(\mathrm{L}_{1} \mathrm{P}_{0} \mathrm{~F}_{0}\right)$ whereas the highest of 43.13 was given by the non $\mathrm{Pb}$-contaminated with high dose of spirulina priming and spraying $\left(\mathrm{L}_{0} \mathrm{P}_{2} \mathrm{~F}_{2}\right)$ which surpassed the lowest by $348 \%$. This demonstrate considerable alleviating effect caused by spirulina seed priming and foliar spray against the negative $\mathrm{Pb}$ effect . The main effect of $\mathrm{Pb}$ contamination was a decrease of $23.6 \%$. The decrease was particularly high(-41.4\%) where no spirulina was applied. \%. Where spirulina was given at the high dose (of both methods combined ), the negative effect of $\mathrm{Pb}$ was 20.8 Effectiveness of spirulina spray surpassed its priming counterpart; Spray caused 24.3 and $80.2 \%$ increases at the low and high dose respectively compared with 19.3 and $35.4 \%$ respectively by the priming method.

Assessment of plant growth, chlorophyll
,carotenoids and photosynthetic activity:

The considerable decrease in plant growth, chlorophylls and carotenoids as a result of $\mathrm{Pb}$ contamination is a demonstration of retardation and toxicity caused by this element. Pollution of soil with $\mathrm{Pb}$ inhibits growth and proper functions of systems in many plant species (Sharma and Dubey 2005; Han et al., 2008; Liu et al. 2008; Zhou et al., 2010). Retardation of photosynthetic processes is an outcome of $\mathrm{Pb}$ toxicity (Patra et al., 2004; Dogan et al., 2009; Ling and Hong, 2009; Maestri et al., 2010). Lead has a profound negative effect on photosynthesis (Sharma and Dubey, 2005) and causes degradation to plant chlorophyll (Drazkiewicz, 1994). Oxidative cell damage by generating reactive oxygen species 'ROS' is caused by $\mathrm{Pb}$ toxicity (Fargasova, 1994, Dixit et al., 2001, Erdei et al., 2002 and Islam et al., 2011).

On the other hand the positive effects of spirulina on plant growth which are shown in the present study were demonstrated in alleviating $\mathrm{Pb}$ toxicity as well as increasing plant growth. This was evident through spraying as well as seed priming. Toxicity of $\mathrm{Pb}$ decreased pigment contents drastically in plants not treated with spirulina and less in plants treated with spirulina. Spirulina can form associations with plants and produce growth-promoting substances (Nanjappan-Karthikeyan et al., 2007) which enable plant to resist stress conditions (Malik et al., 2001; Song et al., 2005 and Indira and Biswajit, 2012).

A number of research work attributed the decline in photosynthetic rate caused by $\mathrm{Pb}$ to a number of reasons which include the four followings: ABlocked electron transport (Qadir et al., 2004 and Gajic et al., 2009), B- Inhibiting the activities of the 5 Calvin cycle enzymes of RuBP carboxy lase, fructose 1,6-bisphosphatase "FBPase", sedoheptulose 1,7bisphosphatase "SBPase", Ru5P kinase and NADPglyceraldehyde 3-phosphate "GAP" dehydrogenase (Sharma and Dubey, 2005; Mishra et al., 2006 and Liu et al., 2008), C- Distorting the chloroplast ultrastructure (Sharma and Dubey, 2005; Islam et al., 2008), especially through disorganizing the thylakoid arrangement (Basile et al., 2012) . Inhibition of chlorophyll biosynthesis was attributed in part to reduction of $\delta$-aminolevulinic acid dehydratase 
activity (Cargnelutti et al., 2006; Gonçalves et al., 2009; Rossato et al., 2012). Enhancement of cytokinins to plant physiologic activities was stated by Thomas (1996). upon application of algae extracts .The extracts contain auxins which increase vitamins , hormones producing gibberellic acids $\mathrm{GA}_{3}$, and $\mathrm{GA}_{7}$ and vitamin all of which increase photosynthetic activity (O'Dell, 2003). Kowalski et al. (1999) noted positive effects of algae extracts on growth and yield of potato plant (Solanum tuberosum). Foliar application of spirulina to sesame plant (Sesamum indicum) increased its growth parameters. Other positive effects were noted on other plants (Aly and
Esawy 2008; Bhowmik et al., 2010;amal et al., 2010; Chojnacka et al., 2012, Piyanast et al., 2014 and Hicham et al., 2016). Algal extracts contain gibberellic acids (GAs) particularly $\mathrm{GA}_{3}$, and $\mathrm{GA}_{7}$ both of which contribute to proper plant growth (Drazkiewicz, 1994).

Decreased carotenoids in plants is another negative effect of $\mathrm{Pb}$ toxicity noted by Haider et al. ( 2006) on mungo beans (Phaseolus mungo ) and black lentils (Lens culinaris ) and noted also by Li et al. (2012) on rice (Orsa sativa). Photosynthetic electron transport in plant was inhibited by $\mathrm{Pb}$ (Rashid et al., 1994 and Gajic et al., 2009 and Qadir et al., 2004).

Table 4. photosynthetic enzymes activity, Ribulose-1,5-bisphosphate-carboxylase/oxygenase, RuBPCase. Phosphoenol-pyruvate carboxylase enzymes(PEPCase) and $\mathrm{Pb}\left(\mathrm{mg} \mathrm{kg}^{-1} \mathrm{dw}\right)$ in shoots

\begin{tabular}{|c|c|c|c|c|c|c|c|c|c|c|c|c|c|}
\hline \multirow{3}{*}{$\begin{array}{l}\text { Soil } \\
\mathrm{Pb} \\
\text { Poll. } \\
\text { (L) }\end{array}$} & \multirow{3}{*}{$\begin{array}{l}\text { Seed } \\
\text { prime } \\
\text { (P) }\end{array}$} & \multicolumn{12}{|c|}{ Foliar spray $(\mathrm{F})$} \\
\hline & & $\mathrm{F}_{0}$ & $\mathrm{~F}_{1}$ & $\mathrm{~F}_{2}$ & $\begin{array}{l}\text { Mea } \\
\mathrm{n}\end{array}$ & $\mathrm{F}_{0}$ & $\mathrm{~F}_{1}$ & $\mathrm{~F}_{2}$ & Mean & $\mathrm{F}_{0}$ & $\mathrm{~F}_{1}$ & $\mathrm{~F}_{2}$ & Mean \\
\hline & & \multicolumn{4}{|c|}{$\begin{array}{l}\text { Photosynthetic activity } \\
\qquad\left(\mathrm{kBq} \mathrm{mg}^{-1} \mathrm{fw}\right)\end{array}$} & \multicolumn{4}{|c|}{$\begin{array}{l}\text { carboxylase enzymes } \\
\left(\mu \mathrm{mol} \mathrm{CO}_{2} \mathrm{~min}^{-1} \mathrm{mg}^{-1}\right. \\
\text { protein })\end{array}$} & \multicolumn{4}{|c|}{$\mathrm{Pb}\left(\mathrm{mg} \mathrm{kg}^{-1} \mathrm{dw}\right)$} \\
\hline \multirow[t]{3}{*}{$\mathrm{L}_{0}$} & $\mathrm{P}_{0}$ & 16.8 & 18.8 & 23.1 & 19.5 & 53.8 & 69.0 & 78.0 & 66.8 & 0.41 & 0.07 & 0.08 & 0.18 \\
\hline & $\mathrm{P}_{1}$ & 17.9 & 21.6 & 26.8 & 22.1 & 61.4 & 73.2 & 80.6 & 71.8 & 0.05 & 0.05 & 0.07 & 0.05 \\
\hline & $\mathrm{P}_{2}$ & 20.0 & 22.4 & 28.1 & 23.5 & 66.0 & 80.2 & 91.0 & 79.0 & 0.04 & 0.06 & 0.08 & 0.06 \\
\hline Mean & & 18.2 & 21.0 & 26.0 & 21.7 & 0.16 & 0.06 & 0.08 & 0.10 & 0.16 & 0.06 & 0.08 & 0.10 \\
\hline \multirow[t]{3}{*}{$\mathrm{L}_{1}$} & $\mathrm{P}_{0}$ & 11.3 & 15.2 & 17.9 & 14.8 & 11.3 & 15.2 & 17.9 & 14.8 & 7.80 & 4.31 & 3.01 & 5.00 \\
\hline & $\mathrm{P}_{1}$ & 13.7 & 16.8 & 18.2 & 16.2 & 13.7 & 16.8 & 18.2 & 16.2 & 5.00 & 3.11 & 2.40 & 3.50 \\
\hline & $\mathrm{P}_{2}$ & 17.7 & 18.0 & 20.0 & 17.5 & 17.7 & 18.0 & 20.0 & 17.5 & 3.20 & 2.50 & 2.01 & 2.60 \\
\hline Mean & & 14.2 & 16.6 & 18.7 & 16.2 & 5.30 & 5.30 & 2.40 & 3.70 & 5.30 & 5.30 & 2.40 & 3.70 \\
\hline G. Mean & & 16.0 & 19.0 & 22.3 & 19.1 & 2.80 & 1.70 & 1.20 & 1.90 & 2.80 & 1.70 & 1.20 & 1.90 \\
\hline \multicolumn{14}{|c|}{ Means of F } \\
\hline $\mathrm{P}_{0}$ & & 14.0 & 17.0 & 20.5 & 17.2 & 4.10 & 2.21 & 1.60 & 2.60 & 4.10 & 2.21 & 1.60 & 2.60 \\
\hline $\mathrm{P}_{1}$ & & 15.8 & 19.2 & 22.5 & 19.1 & 2.50 & 1.60 & 1.20 & 1.80 & 2.50 & 1.60 & 1.20 & 1.80 \\
\hline \multirow[t]{4}{*}{$\mathrm{P}_{2}$} & & 17.3 & 20.2 & 24.0 & 20.5 & 1.60 & 1.20 & 1.00 & 1.30 & 1.60 & 1.20 & 1.00 & 1.30 \\
\hline & & \multirow{3}{*}{\multicolumn{4}{|c|}{$\begin{array}{l}\text { L: } 0.0001 \text { P: } 0.001 \mathrm{~F}: 0.001 \\
\text { LP :0.002 LF: } 0.001 \text { PF: } \\
\text { 0.004 LFP: } 0.0001\end{array}$}} & \multirow{3}{*}{\multicolumn{4}{|c|}{$\begin{array}{l}\text { L: } 0.009 \text { P: } 0.0007 \text { F:0.0001 } \\
\text { LP :0.03 LF: } 0.0001 \\
\text { PF:0.001 LFP: } 0.0001\end{array}$}} & \multirow{3}{*}{\multicolumn{4}{|c|}{$\begin{array}{l}\text { L: } 0.001 \text { P: } 0.001 \mathrm{~F}: 0.0001 \\
\text { LP :0.02 LF: } 0.001 \text { PF: } 0.001 \\
\text { LFP: } 0.001\end{array}$}} \\
\hline & & & & & & & & & & & & & \\
\hline & & & & & & & & & & & & & \\
\hline
\end{tabular}

Phosphosynthetic enzymes activity.

Table 4 shows that the activity of photosynthesis enzymes (in Ribulose-1,5-bisphosphatecarboxylase/oxygenase,RuBPCase). Activities are of carboxylating enzymes (Phosphoenol pyruvate carboxylase "PEPC, EC 4.1.1.31") and ribulose1,5bisphosphate carboxylase (RuBPC, EC 4.1.1.39). Values ranged between 11.3 and $28.1 \mathrm{kBq} \mathrm{mg}$ (kilo benzoquinone per $\mathrm{mg} f \mathrm{w}$ ). The lowest was given by the $\mathrm{Pb}$ non- primed non-sprayed $\left(\mathrm{L}_{1} \mathrm{P}_{0} \mathrm{~F}_{0}\right)$ while the highest was caused by the non-polluted highly primed and sprayed $\left(\mathrm{L}_{0} \mathrm{P}_{2} \mathrm{~F}_{2}\right)$ treatment ; an increase of $149 \%$.This indicates a very high alleviating effect caused by spirulina seed priming combined with foliar spray against the negative effect of $\mathrm{Pb}$ on plant in photosynthetic activity. The main effect of $\mathrm{Pb}$ contamination was a decrease of $25.3 \%$. Where no spirulina was given, the decrease was particularly high
, being $-32.7 \%$, but where spirulina was given at the high dose (of the two methods combined), the negative effect of $\mathrm{Pb}$ was $-28.8 \%$. Effectiveness of spirulina foliar spray surpassed its priming counterpart; the foliar spray increased the activity by averages of 18.7 and $39.4 \%$ at the low and high dose respectively compared with 11.0 and $19.1 \%$ at the low and high priming methods respectively.

\section{Phosphoenol-pyruvate carboxylase enzymes (CPEPase)}

Table 5 shows CPEPase activity as affected by $\mathrm{Pb}$ contamination and spirulina treatment. Values ( $\boldsymbol{\mu m o l}$ $\mathrm{CO}_{2} \mathbf{~ m i n}^{-1} \mathbf{~ m g}^{-1}$ protein) ranged from 41.7 to 91.0 $\mu \mathrm{mol} \mathrm{CO} \mathrm{Cin}^{-1} \mathrm{mg}^{-1}$ protein . Results show patterns very much similar to those of the photosynthetic activity. The lowest was given by the $\mathrm{Pb}$ none-primed non-sprayed $\left(\mathrm{L}_{1} \mathrm{P}_{0} \mathrm{~F}_{0}\right)$ while the highest was caused by 
the non-polluted highly primed and sprayed $\left(\mathrm{L}_{0} \mathrm{P}_{2} \mathrm{~F}_{2}\right)$ .The high value surpassed the low one by $118 \%$ indicating a considerable increase in enzyme activity as a result of subjecting the contaminated plant to a high dose of combined spirulina seed priming and foliar spraying. The main effect of $\mathrm{Pb}$ contamination was a decrease of $26.9 \%$. Where no spirulina was given the decrease was $22.5 \%$. Under conditions of spirulina at the high dose of combined priming+spraying the negative effect of $\mathrm{Pb}$ was a decrease of $25.4 \%$. Foliar spray surpassed its priming counterpart .Foliar spray increased the activity by averages of 18.2 and $38.5 \%$ at the low and high dose respectively compared with respective 7.6 and $19.1 \%$.

\section{Contents of $\mathrm{Pb}$ in plant:}

Contamination with $\mathrm{Pb}$ caused a drastic increase in plant $\mathrm{Pb}$. Content in shoots under no $\mathrm{Pb}$ application was $0.41 \mathrm{mgkg}^{-1} \mathrm{dw}$. Content in plant subjected to contamination increased by as much as 18 times (Table 4) .Spirulina decreased $\mathrm{Pb}$ in plant. The lowest content of $0.04 \mathrm{mgkg}^{-1} \mathrm{dw}$ occurred in the noncontaminated treatment where seeds were primed at the high spirulina dose and no spray was done $\left(\mathrm{L}_{0} \mathrm{P}_{2} \mathrm{~F}_{0}\right)$. The highest existed in the $\mathrm{Pb}$ contaminated non-spirulina treated plants $\left(\mathrm{L}_{1} \mathrm{P}_{0} \mathrm{~F}_{0}\right)$ where $\mathrm{Pb}$ content were 19 times those in the lowest. The main effect of $\mathrm{Pb}$ contamination was an average increase of 36 times. Spirulina suppressed contents of $\mathrm{Pb}$ in plant. Plants receiving spirulina at the high combined dose and growing on non- $\mathrm{Pb}$ contaminated soil showed as much as $99 \%$ decrease in $\mathrm{Pb}$ as compared with those grown on $\mathrm{Pb}$-contaminated non-spirulina treated ones.

The spray method of spirulina was more effective than the priming method. Decreases caused by spraying averaged 39.3 and $57.1 \%$ at the low and high dose respectively compared with 30.8 and $50.0 \%$ at the low and high dose of priming respectively.

\section{Assessment of Phosphosynthetic and PEPCase activities and $\mathrm{Pb}$ in plant}

The retarding and toxic effects of $\mathrm{Pb}$ was manifested in decreased phosphoenol pyruvate carboxylase activity in plants grown on the $\mathrm{Pb}$ contaminates soil. In a study by van Assche and Clijsters (1990) where rocket was grown on a soil contaminated with $350 \mathrm{mg}$ $\mathrm{Pb} \mathrm{kg}{ }^{-1}$, a considerable decrease occurred in phosphoenol pyruvate carboxylase (PEPC, EC 4.1.1.31) and ribulose1,5-bisphosphate carboxylase (RuBPC, EC 4.1.1.39) enzymes (superoxide dismutase activity, EC1.15.1.1; catalase activity, EC 1.11.1.6 and peroxidase activity, EC 1.11.1.7. Lead inhibits activities of enzymes of the reductive pentose phosphate pathway (Hampp et al., 1973). The activity of ribulose-bis-phosphate carboxylase/oxygenase was inhibited in spinach (Spinacia oleracea) grown in a nutrient solution containing $1555 \mathrm{ug} \mathrm{\textrm {Pb } \mathrm { L } ^ { - 1 }}$ as nitrate (Vallee and Ulmer, 1972)..Spirulina increases plant growth and enables plants to withstand adverse effect (LiuShiMing and Liang-ShiZhong ,1998).. It was reported that Increased contents of $\mathrm{Pb}$ in plants grown on $\mathrm{Pb}$-contaminated soils occurred in presence of chelating substances in soil (Huang et al 1997). Spirolina increases plant growth, protein and carbohydrates (Jagannath et al. 2002)

\section{Contents of $\mathrm{N}, \mathrm{P}$ and $\mathrm{K}$ in plant leaves: $\mathrm{N}$ contents}

Contents of $\mathrm{N}$ in leaves were affected negatively by $\mathrm{Pb}$ contamination and positively by spirulina application (Table 5). The lowest of $20.1 \mathrm{mgg}^{-1} \mathrm{dw}$ occurred upon application of $\mathrm{Pb}$ where no spirulina was given $\left(\mathrm{L}_{1} \mathrm{P}_{0} \mathrm{~F}_{0}\right)$ and the highest was given by non $\mathrm{Pb}$-treatment receiving the high dose of both priming and spraying of spirulina $\left(\mathrm{L}_{\mathrm{o}} \mathrm{P}_{2} \mathrm{~F}_{2}\right)$ which surpassed the lowest by $200 \%$ indicating a marked alleviation of the suppression caused by $\mathrm{Pb}$.

The main effect of $\mathrm{Pb}$ was a decrease of $27.9 \%$. The decrease was particularly high $(38.7 \%)$ where no spirulina was applied. In presence of spirulina at its combined high dose of spray+priming, the decrease was less $(36.4 \%)$. The alleviating effect of spraying spirulina surpassed the priming effect particularly where the high dose was used. Average increases due to priming were 12.1 and $35.1 \%$ at the low and high doses respectively compared with 31.0 and $48.7 \%$ respectively using the spray method.

\section{$P$ contents}

Results resembled those of the $\mathrm{N}$ contents. Plants growing on $\mathrm{Pb}$ contaminated soils were negatively affected by $\mathrm{Pb}$ and contained lower contents of $\mathrm{P}$ (Table 5). On the other hand spirulina affected plants positively .The lowest $\mathrm{P}$ of $11.0 \mathrm{mgg}^{-1} \mathrm{dw}$ was given upon application of $\mathrm{Pb}$ with no spirulina applied $\left(\mathrm{L}_{1} \mathrm{P}_{0} \mathrm{~F}_{0}\right)$ and the highest was given by the non $\mathrm{Pb}-$ treatment receiving the high combined dose of primed and sprayed spirulina $\left(\mathrm{L}_{0} \mathrm{P}_{2} \mathrm{~F}_{2}\right)$ which surpassed the lowest by $331 \%$ indicating a marked alleviation of the suppression caused by $\mathrm{Pb}$. The main effect of $\mathrm{Pb}$ was a decrease of $21.8 \%$. The decrease was particularly high, being $44.4 \%$ where no spirulina was applied. In presence of spirulina at its combined high dose of spray+priming, the negative effect was less $(24.6 \%)$.The alleviating effect of spraying spirulina surpassed that of the priming particularly where the high dose was used. Priming caused increases averaging 18.8 and $41.6 \%$ at the low and high doses respectively compared with 28.1 and $65.6 \%$ respectively using the spray method. 
Table 5. NPK $\left(\mathrm{mgg}^{-1} \mathrm{dw}\right.$ of rocket leaves grown on Pbl contaminated soil as affected with Spirulina platensis treatment

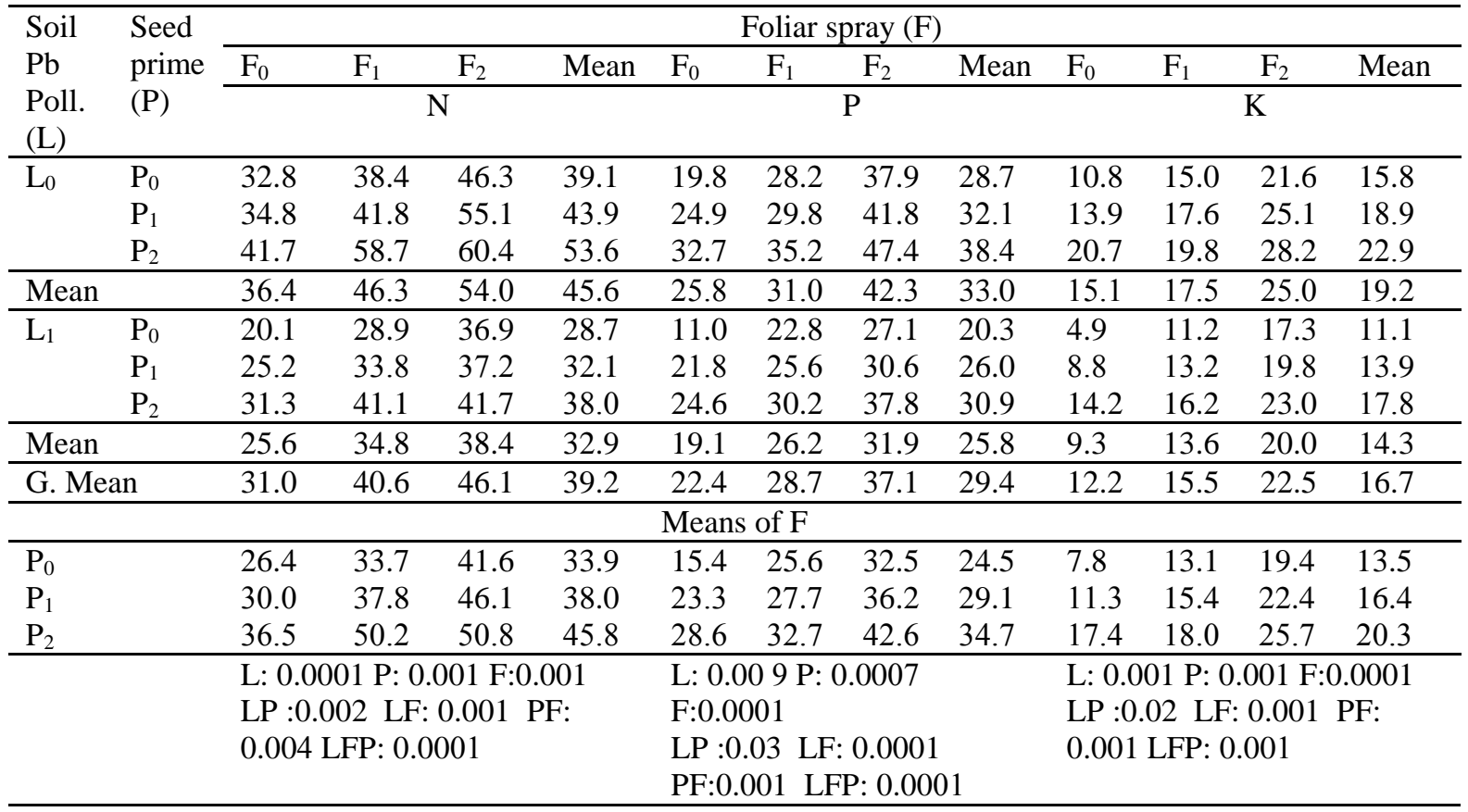

See notes of Table 2 for designation of treatments.

\section{$K$ contents}

The pattern of response to contents of $\mathrm{K}$ in plan was rather similar to those of the contents of $\mathrm{N}$ and $\mathrm{P}$. Plants growing on $\mathrm{Pb}$ contaminated soils contained lower $\mathrm{K}$ than those non-contaminated (Table 5) and spirulina showed positive effect alleviating the retarding effect of $\mathrm{Pb}$.The lowest $\mathrm{K}$ of $4.9 \mathrm{mgg}^{-1} \mathrm{dw}$ was given upon application of $\mathrm{Pb}$ with no spirulina applied $\left(\mathrm{L}_{1} \mathrm{P}_{0} \mathrm{~F}_{0}\right)$ and the highest was given by the non $\mathrm{Pb}$-treatment receiving the high combined dose of primed and sprayed spirulina $\left(\mathrm{L}_{0} \mathrm{P}_{2} \mathrm{~F}_{2}\right)$ which surpassed the lowest by $476 \%$ indicating an extremely high alleviation of the suppression caused by $\mathrm{Pb}$. The main effect of $\mathrm{Pb}$ was an average decrease of $37.6 \%$, and the decrease was particularly high $45.6 \%$ where no spirulina was applied. In presence of spirulina at its combined high dose of spray+priming, the negative effect of $\mathrm{Pb}$ was less $(18.4 \%)$.The alleviating effect of spraying spirulina surpassed that of the priming particularly where the high dose was used. Priming caused increases averaging 21.5 and $50.4 \%$ at the low and high doses respectively compared with 27.0 and $84.4 \%$ respectively using the spray method.

\section{Assessment of NPK contents in plant as affected by $\mathrm{Pb}$ and spirulina:}

The retarding effect of $\mathrm{Pb}$ contamination was inflicted on plants and their contents of plant (Sharma and Dubey 2005; Han et al., 2008; Liu et al. 2008; Zhou et al., 2010). Cell damage is caused by $\mathrm{Pb}$ through many mechanisms including generating reactive oxygen species 'ROS' (Fargasova, 1994, Dixit et al., 2001, Erdei et al., 2002 and Islam et al., 2011). Was shown to cause imbalances in the uptake of plant nutrients of $\mathrm{K}, \mathrm{Ca}, \mathrm{Mg}, \mathrm{Mn}, \mathrm{Zn}, \mathrm{Cu}, \mathrm{Fe}$ within the tissues through blocking their absorption access via plant roots (Pallavi and Rama, 2005).

On the other hand the positive effect of Spirulina platensis is most certainly due to its being a biofertilizer containing plant nutrients besides its ameliorating properties (Misra and Kasushik, 1989, Singh and Trehan, 1973 and venkataraman and Neelakantan, 1969).. A number of workers observed an increase in rice seed germination, root and shoot growth, weight of rice grains and their $\mathrm{N}$ content with use of cyanobacteria (Misra and Kasushik, 1989, Singh and Trehan, 1973 and venkataraman and Neelakantan, 1969). Analysis of Spirulina dry biomass revealed that it contains nitrogen, phosphorus and potassium, respectively (Aly and Esawy, 2008).

\section{References}

Adam, M.S.1999. The promotive effect of the cyanobacterium Nostoc muscorum on the growth of some crop plants. Acta Microbiol. Polonica 48(2): 163-171.

Ahmed, F. F. Ibrahiem, A. A., Mansour, A. E. M., Shaaban, E. A. and El- Shamaa, M. S. 2011: Response of Thompson seedless grapevines to application of some amino acids enriched and organic biofertilization . Res. J. of Agric. Biolog. Sci 7 (2), 282-286. 
Ali, L..K.M and Mostafa, S..S.M 2009. Evaluation of potassium humate and Spirulina platensis as bio-organic fertilizer for sesame plants grown under salinity stress. Egypt. J. Agric. Res. 87(1): 369-388.

Alloway, B.J., and Ayres, D. C., 1997. Chemical principles of environmental pollution. Blackie Acad. Profess., Glasgow,UK.

Aly,M. S. and Esawy,M.A. 2008. Evaluation of Spirulina Platensis as bio-stimulator for organic farming systems. J. Genet. Engin. Biotech. 6(2): 17

Attememe. J. Y. A., 2009. The effect of humic acid and sea weed extracts on the growth, chemical characteristics and oil characteristics of Rosmarinus officinalis L. 6th Sci. Conf., Biol. Dept., College of Education, University of Tikrit. Plants Sci. pp 1-17.

Basile A, Sorbo S, Pisani T, Paoli L, Munzi S. and Loppi S.2012. Bioacumulation and ultrastructural effects of $\mathrm{Cd}, \mathrm{Cu}, \mathrm{Pb}$ and $\mathrm{Zn}$ in the moss Scorpiurum circinatum (Brid.). Fleisch. \& Loeske. Environ. Poll. 166: 208-211.

Bhowmik D., Dubey J. and Mehra S., 2010. Evaluating potential of spirulina as inoculant for pulses. Acad. J. Plant Sci. 3(4): 161-164.

Canovas,J.L., and Kornberg, H.L.1969. Phosphoenol- pyruvate-carboxylase from Escherichia coli, p.288-292. In J.M. Lowenstein (ed.), Methods of enzymology, vol. XIII. Academic Press Inc., NY,USA.

Black, C.A. ,Evans,D.D., Ensminger, L.E, White, J.L. and Clerk, F.E. 1965.Methods of soil analysis. Soil Sci Soc. Am, Madison, WI,USA.

Cargnelutti D, Tabaldi, L.A., Spanevello, R.M., deOliveira, J. G., Battisti V., Redin M., Linares, C.E., Dressler, V.L., deMoraes, F.E.M., Nicoloso, F.T., Morsch, V.M. and .Schetinger, M.R. 2006. Mercury toxicity induces oxidative stress in growing cucumber seedlings. Chemosphere 65(6): 999-1006.

Chojnacka K., Saeid A., Witkowska Z., Tuhy L. 2012. Biologically active compounds in seaweed extracts - the prospects for the application. The Open Conf. Proceed. J. 3:20-28.

Ciferri, O and Tibani, O. 1985. The biochemistry and industrial potential of Spirulina. Ann. Rev. Microb. 39: 503 -526.

Csuros M. 1994. Introduction to metals. In: Environmental sampling and analysis for technicians. Boca Raton, Lewis Publ., Denmark.

Dixit V, Pandey V, Shyam R.2001. Differential antioxidative responses to cadmium in roots and leaves of pea (Pisum sativum). J. Exp. Bot. 52(358): 1101-1109.

Dogan M, Saygideger, S.D. and Colak U. 2009. Effect of lead toxicity on aquatic macrophyte Elodea canadensis Michx. Bull. Environ. Contam. Toxicol. 83(2): 249-254.
Drazkiewicz M.1994. Chlorophyll-occurrence, functions, mechanism of action, effects of internal and external factors. Photosynthetica 30: 321-331.

Elarroussia, H. ,Elmernissia, N., Benhimaa R, El Kadmiria, I.M., Bendaou. N., Smouni A and Wahbya, I. 2016. Microalgae polysaccharides a promising plant growth biostimulant. J. Algal Biomass Utln. 7 (4): 55-63.

Erdei, S., Hegedus. A, ,Hauptmann. G., Szalai, J. and Horvath, G.2002. Heavy metal induced physiological changes in the antioxidative response system. Proc. 7th Hung. Cong. Plant Physiol., pp. 89-90.

Fargasova A.1994. Effect of $\mathrm{Pb}, \mathrm{Cd}, \mathrm{Hg}$, $\mathrm{As}$, and $\mathrm{Cr}$ on germination and root growth of Sinalpis alba seeds. Bull. Environ. Contam. Toxicol. 52(3): 452-456.

Gajić, G.1,, Mitrović, M., Pavlović, P., Stevanović, B., Djurdjević, L. and Kostić, O..2009. An assessment of tolerance of Ligustrum ovalifolium hassk.to traffic-generated $\mathrm{Pb}$ using physiological and biochemical markers. Ecotox. Environ. Saf. 72(4):1090-1101.

Godlewska, K. Michalak , I., Pacyga, P., Baśladyńska, S. and Chojnacka, K. 2019 . Potential applications of cyanobacteria: Spirulina platensis filtrates and homogenates in agriculture, World J. Microbiol. Biotechnol. 35(6): 80-92

Gonçalves, J.F., Tabaldi, L.A., Cargnelutti D, Pereira, L.B., Maldaner J, Becker, A.G., Rossato, L.V., Rauber R, Bagatini, M.D., Bisognin, D.A., Schetinger, M.R.C., Nicoloso, F.T..2009.Cadmium-induced oxidative stress in two potato cultivars. Biometals, 22(5):779-792.

Haggag, L.F., Mustafa, N.S., Shahin, M.F.M., Genaidy,E.A.E., Mahdy ,H.A. 2014. Impact of NPK, humic acid and algae extract on growth of "Aggizi" olive seedlings cultured in sandy soil under greenhouse condition. J. Agric. Techn. 10(6):1599-1606.

Haider S, Kanwal S, Uddin F, Azmat R.2006. Phytotoxicity of $\mathrm{Pb}$. II. changes in chlorophyll absorption spectrum due to toxic metal $\mathrm{Pb}$ stress on Phaseolus mungo and Lens culinaris. Pakistan J. Biol. Sci. 9(11): 2062-2068.

Hampp R, Ziegler H, Ziegler I. 1973. Influence of lead ions on the activity of enzymes of the reductive pentose phosphate pathway. Biochem Physiol Pflanz 164:588-595.

Han Y, Huang S, Gu J, Qiu S, Chen J.2008. Tolerance and accumulation of lead by species of Iris L. Ecotoxicology 17(8): 853-859.

Hegazi,A.Z., Mostafa, S.M. and Ahmed,H.M.I. 2010. Influence of different cyanobacterial application Methods on growth and seed production of common bean under various levels of mineral nitrogen fertilization. Nature and Science 8 (11):183-194.

Huang, J. W. Chen , J. ,Berti, W. R. and Cunningham, S.D. 1997. Phytoremediation of 
lead-contaminated soils: Role of synthetic chelates in lead phyto-extraction. Environ. Sci. Technol. 31:800-805

Indira, $\mathbf{P}$ and Biswajit, R. 2012. Commercial and industrial applications of micro-algae - A review. J. Algal Biomass Utln. 3(4): 89-100.

Islam E, Liu D, Li T, Yang X, Jin X, Khan, M.A., Mahmood Q, Hayat Y, Imtiaz M.2011. Effect of $\mathrm{Pb}$ toxicity on the growth and physiology of two ecotypes of Elsholtzia argyi and its alleviation by Zn. Environ. Toxicol. 26(4): 403-416.

Islam E, Liu D, Li T, Yang X, Jin X, Mahmood Q, Tian S, Li J.2008. Effect of Pb toxicity on leaf growth, physiology and ultrastructure in the two ecotypes of Elsholtzia argyi. J. Hazard. Mater. 154(1-3):914-926.

Jagannath, S.B.A., Umapati-Dengi, EshwarlalSedamakar. 2002. Algalization studies on chickpea (Cicer arietinum L). Biotech. Microbes and Sustainable Utilization. Sci. Publ. India pp 145-150.

Karthikeyan N, Prasanna R, Nain L, Kaushik, B.D. 2007. Evaluating the potential of plant growth promoting cyanobacteria as inoculants for wheat. European J. Soil Biol. 43(1): 23-30.

Kowalski B, Jager, A. K., Vanstaden J. 1999. The effect of a seaweed concentrate on the in vitro growth and acclimatization of potato plants. Potato Research. 42(1):131-139.

Leduy, A and Thorein, N. 1977. An improved method for optical density measurement of semimicro bluegreen algae Spirulina maxima. Biotech. Bioeng. 19: 1219 - 1224.

Li X, Bu N, Li Y, Ma L, Xin S, Zhang L.2012. Growth, photosynthesis and antioxidant responses of endophyte infected and non-infected rice under lead stress conditions. J. Hazard. Mater. 213214:55- 61 .

Ling Q, Hong, F.S. 2009. Effects of $\mathrm{Pb}^{2+}$ on the structure and function of photosystem II of Spirodela polyrrhiza. Biol. Trace Elem. Res. 129(1-3):251-260.

Liu D, Li, T.Q., Jin, X.F., Yang, X.E., Islam E, Mahmood Q.2008. Lead induced changes in the growth and antioxidant metabolism of the lead accumulating and non-accumulating ecotypes of Sedum Alfredii. J. Integr. Plant Biol. 50(2): 129140.

Liu-ShiMing, Liang-ShiZhong. 1998. Effect of extract from Nostoc commune cells on the growth of sprouts and seedlings of mung bean (Phaseolus radiatus). Pl. Physiol. Commun. 29(6):429-431.

Maestri E, Marmiroli M, Visioli G, Marmiroli N.2010. Metal tolerance and hyperaccumulation: Costs and trade-offs between traits and environment. Environ. Exp. Bot. 68(1):1-13.

Malik, F.R., Ahmed S, Rizki, Y.M. 2001. Utilization of lingo-cellulosic waste for the preparation of nitrogenous biofertilizer. Pakistan J. Biol. Sci. 4:1217-1220.

Metzner H, Rou H, Senger H. 1965.Unter suchungen zur synchronisier barkeit ein zeiner pigment. Mangol Mutanten von chlorella. Planta; 65: 186.

Mishra S, Srivastava S, Tripathi, R.D., Kumar R, Seth, C.S., Gupta, D.K. 2006. Lead detoxification by coontail (Ceratophyllum demersum L.). involves induction of phytochelatins and antioxidant system in response to its accumulation. Chemosphere 65(6):10271039.

Mishra, S. and Kaushik, B.D. 1989. Growth promoting substances of Cyanobacteria. I. Vitamins and their influence on rice plants. Proc. Indian Nation. Sci. Acad. B55:295-300.

Moussa, H. R. 2006. Role of gamma irradiation in regulation of $\mathrm{NO}_{3}$ Level in Rocket (Eruca vesicaria sub sp. sativa) plants. Russ. J. Plant Physiol. 53:193-198.

Nas, F.S., Ali, M. 2018 The effect of lead on plants in terms of growing and biochemical parameters: A review. MOJ Eco. Environ. Sci. 3(4):265-268.

O' Dell, C. 2003. Natural plant hormones are bio stimulants helping plants develop high plant antioxidant activity for multiple benefits. Virginia Vegetable, Small Fruit and Specialty Crops. 2(6):1-3

Patra M, Bhowmik N, Bandopadhyay B, Sharma A.2004. Comparison of mercury, lead and arsenic with respect to geno-toxic effects on plant systems and the development of genetic tolerance. Environ. Exp. Bot. 52(3):199-223.

Qadir S, Qureshi, M.I., Javed S, Abdin, M.Z.2004. Genotypic variation in phytoremediation potential of Brassica juncea cultivars exposed to Cd stress. Plant Sci. 167(5):1171-1181.

Rashid A, Camm, E.L., Ekramoddoullah, A.K.1994. Molecular mechanism of action of $\mathrm{Pb}$ and $\mathrm{Zn}^{2+}$ on water oxidizing complex of photosystem II. FEBS Lett., 350(2-3): 296-298.

Robinson, S.P. and Portis, A.R. 1988. Involvement of stromal ATP in the light activation of ribulose1,5-bisphosphate carboxylase/oxygenase in intact isolated chloroplasts. Plant Physiol 86:293-298.

Rossato, L.V., Nicoloso, F.T., Farias, J.G., Cargnelluti D, Tabaldi, L.A., Antes, F.G., Dressler, V.L., Morsch, V.M., Schetinger, M.R. 2012. Effects of lead on the growth, lead accumulation and physiol. responses of Pluchea sagittalis. Ecotoxic., 21(1): 111-123.

Sharma P, Dubey,R.S. 2005. Lead toxicity in plants, Brazilian J. Plant Physiol. 17(1):35-52

Sharma P, Dubey, R.S . 2005. Lead toxicity in plants. Braz. J. Plant Physiol. 17(1):35-52.

Singh, V.P. and Trehan, A. 1973. Effect of extocellular products of Aulosira fertilissima on the growth of rice seedlings. Pl. Soil 38:457-464. 
Song T , Martensson L, Eriksson T, Zheng W, Rasmussen U. 2005. Biodiversity and seasonal variation of the cyanobacterial assemblage in a rice paddy field in Fujian, China. Federation Europ. Mater. Soc. Microbiol. Eco. 54:131-140.

Sornchai P, Saithong N, Srichompoo Y, Unartngam A and Iamtham S. 2014. Effect of spirulina maxima aqueous extract on seed germination and seedling growth of mung bean, vigna radiata and rice, oryza sativa var. japonica . J. Issaas 20(2):77-84.

Thomas, S.C. L. 1996. Nutrient weeds as soil amendments for organic cally growth herbs. J. Herb. Spices Medic. Pl. 4(1):3-8.

Vallee, B.L., Ulmer, D.D. 1972. Biochemical effects of mercury, cadmium and lead. Ann. Rev. Biochem. 41:91-128.
Van Assche F, Clijsters H. 1990. Effects of metal on enzyme activity in plants. Plant Cell Environ. 13:195-206.

Venkataraman, G.S. and Neelakantan, S.J. 1969. Effect of cellular constituents of nitrogen fixing blue green alga Cylindrospermum on root growth of rice plants. J. Gene. Appl. Microbiol. 13:53-62.

Vonshak A. 1986. Laboratory techniques for cultivation of microalgae. In handbook Vonshak A. and Richmond A.(eds) Mass production of blue-green algae Spirulina. An overview. Biomass 15:233-247.

Zhou Y, Huang S, Yu S, Gu J, Zhao J, Han Y, Fu J.2010. Physiological response and subcellular localization of lead and cadmium.in Iris pseudacorus L. Ecotox. 19(1):69-76.

\footnotetext{
الأثر التخفيفي للسبيرولينا Spirulina Platensis على نبات الجرجير النامي في ترية ملوثة بالرصاص

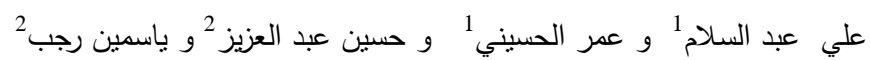$$
\text { 1 قسم الأراضي والمياه كلية الزراعة بمشتهر جامعة بنها .. } 2 \text { قسم الأراضي والمياه مركز البحوث النووية هيئة الطاقة الذرية }
$$ 